
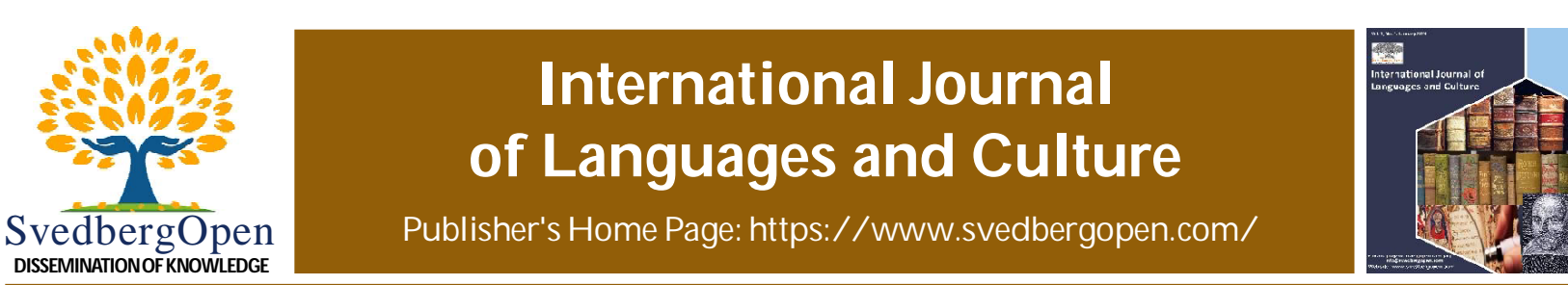

\title{
Cultural Inhibitions as Threat to Advancement of African Women: The Case of Mariama Ba's So Long a Letter
}

Agbasiere, Chijioke $^{\mathrm{l}^{*}}$

${ }^{1}$ Department of Theatre Arts, Chukwuemeka Odumegwu Ojukwu University, Igbariam Campus, Nigeria. E-mail: agbachiji2008@yahoo.com

\section{Article Info}

Volume 1, Issue 3, September 2021

Received : 08 March 2021

Accepted : 18 August 2021

Published : 05 September 2021

doi: 10.51483/IJLC.1.3.2021.1-7

\begin{abstract}
In this presentation, the various cultural factors which inhibit the advancement of women in their struggles to make a better living are examined. The aim is to ensure that an enabling environment which will empower the women is created in order to pave the way for them to make maximum contributions to the development of their society. This is based on recorded experiences gathered from Africa which include aspects of culture such as religious, economic and social factors that have been misapplied by some men to ensure that the women are perpetually subjugated to suit their purpose. Again, through cultural institutions like the family, marriage and kingship structures, limitations are placed on the aspirations of the women. For example, the female cannot freely like her male counterpart aspire to become a King, Priest, or Imam as the society forbids her from making an attempt to occupy such positions. It is noted that in our traditional society such as the Igbo, Yoruba and Hausa, Mandinka, the Tukulor, women are generally not allowed to participate in most of the decision making processes that affect their lives. It is observed that the women have great potentials that will impact positively on the society when it is properly harnessed in relation to that of the men. It is therefore submitted that when an equal opportunity is created for both male and female, the society will benefit as well as develop because every segment will be contributing to its welfare.
\end{abstract}

Keywords: Cultural inhibitions, Women empowerment, African women, Better living

(C) 2021 Agbasiere, Chijioke. This is an open access article under the CC BY license (https://creativecommons.org/licenses/by/4.0/), which permits unrestricted use, distribution, and reproduction in any medium, provided you give appropriate credit to the original author(s) and the source, provide a link to the Creative Commons license, and indicate if changes were made.

\section{Introduction}

It is obvious based on records of experiences gather from various parts of the world especially Africa as well as the Middle East that a section of the human race and perhaps the most important- the female gender is marginalized to the point of being inhibited from advancing freely in life like her male counterpart. This situation arises due to some cultural observances fashioned and sustained by some men to perpetually keep the women in control and subjugate them to their wishes in the guise of practicing their culture or tradition. Experience has also shown that culture is supposed to be an accepted way of life by a group of people living within the same geographical area. However, this has ironically been used as an instrument of inhibition and oppression against the female gender. Moreover, it is observed that culture ought to be dynamic based on the realities of events occurring in human society but is most of the time arbitrarily applied in its rawness without consideration to the feelings of some members and changes or development taking place globally.

\footnotetext{
* Corresponding author: Agbasiere, Chijioke, Department of Theatre Arts, Chukwuemeka Odumegwu Ojukwu University, Igbariam Campus. E-mail: agbachiji2008@yahoo.com
} 
Realistically, one expects that culture should be flexible as well as adaptable to the aspirations of its adherents to instill in them a sense of freedom and cohesion which will galvanize them into positive action for the benefit of their society. So, culture should basically serve as a point of solidarity to bring men and women of goodwill together but it is unfortunately misapplied by some men as a weapon to cause division among members of the same family, village, town, and country which breeds hate. In all the situations where culture has been misapplied or abused, the women are usually the victims which place limitation on them. It is based on the above cultural practices which are known to have been used to inhibit the advancement of women generally that prompted this writing. The hope is that a suitable dynamic cultural setting operational on equitable basis should be created for both genders to enable them advance and realise their aspirations within the society.

\section{Clarification of Terms}

It is pertinent to enhance our appreciation of the issues at stake in this presentation by clarifying the keyword culture which form the fundamental basis of the concept expressed. Let us begin by referring to the formulators of the Cultural Policy for Nigeria who defined culture as:

The totality of the way of life evolved by a people in their attempts to meet the challenge of living in their environment which gives order and meaning to their social, political, economic, aesthetic and religious norms and modes of organization thus distinguishing a people from their neigbors (5).

From the above, it is seen that culture is meant to bring order and meaning to the people living within a particular area. It is clear that culture is designed to assist those living in a society to realize their collective aspirations as well as potentials for the benefit of every member. In a functional society which has regard for its culture every member contributes to its welfare and development as no section is marginalized or "looked down" on as the inferior that should not be given the chance to express opinion on matters affecting their lives.

Another aspect of culture is explored by Margaret Meads who observes that:

Culture is an abstraction from the body of learned behavior which a group of people who share the same tradition transits entire to their children and in part to adult immigrants who become members of the society. It covers not only the art and sciences, religious and philosophies... but also the system of technology, the political practices, the small intimate habits of daily life (Agunloye, 2006).

The above further buttresses the fact that culture is not static or "rubber stamped" by the ancestors but an experience that is learned and shared by a group of people who live together. It could be changed or influenced by the events which take place in neighboring communities or by immigrants. The fundamental aspect of culture is its formulation and acceptance by the people through constant practice. It is not meant to be foisted or imposed on the people but emanates through gradual process before being taken as a way of life. The people make as well as change their culture depending on their daily experiences which may be positive or negative. So, for some men to impose a particular pattern of behavior on women which creates discomfort to them and insist that it should be continued because it is their culture is unacceptable. This is because culture is part of human society which is dynamic and once an aspect is found to be causing problem, it should then be changed. This flexible tendency experienced through cultural practice prompted Irene Agunloye to emphasize that:

Culture is not God-made, but a man-made systematic integrated whole. This follows that as a social construction, man can deconstruct it systematically too (17).

This also goes to show that man as the designer of his culture can redesign it at any point to suit his purpose and satisfy his aspirations. Culture is designed to benefit the society and as such should not be used as instrument of intimidation or subjugation or even humiliation as it is being practiced today in some parts of the world where women are oppressed.

At this juncture, it is important to highlight the various aspects of culture which have continued to support the subjugation of women. These include religious, economic and social observances. The understanding will enable us appreciate the seriousness of the issues at stake. Our examples will be taken from Africa and the Middle East where the application makes our position clearer.

\section{Religion}

Experience has shown that religion is part of human society as it is practiced in diverse forms which depend on the belief system of the individual or group. It is the common hope and expectation of the adherents that religion will provide the 
channel through which they establish communication link with the creator as a means to attend salvation. So, if religion for example Christianity, Islam or African Traditional Religion is misused by some privileged adherents who boast of possessing knowledge more than others as instrument of oppression or deceit, it then becomes contradictory. These religious oppressors often claim to have powers to execute God's will on earth as they deem fit to suit their purpose. Due to their misinterpretation of what they claim as God's command, they tend to ascribe strict rules or regulations that are most often too difficult to observe by their congregation who are mostly women.

In some religious culture such as African Traditional Religion and Eastern Religion, women are restricted and compelled to adhere to a particular behavioral pattern. For example, there are some hours of the day they are not allowed to move about and even if they do are also expected to dress in veil or over-flowing gown to cover their entire body irrespective of the weather condition. Even when the temperature is very high, they are expected to comply with the dressing code in order to pacify the ever sensitive and insatiable "eyes" of the male fold. This is also designed to keep them reserved at the service of a particular man so that other men will not be attracted to them. It is assumed then that when the women dress ordinarily, they become agents of temptation to the men who are always watching their movement in readiness to devour or accuse them of wrong doing at the slightest provocation. In a study on "Women as Sex Symbols in Nigerian Home Videos" Daniel Enim aptly captures this uncomfortable life style that many women are subjected to live when she observes that:

The patriarchal image of the woman transcends the cultural and even affects the religions believes of the people...As a result, the woman must live all her life in subjection to man's will. Always seen nor heard. To emphasize this, in Saudi Arabia, for instance, a woman is not supposed to walk the streets unaccompanied by a young male. This is supposed to show that she is responsible (198).

The situation is so tense that the women are expected to be always conscious of their movement, dressing and the way they talk or laugh. To say the obvious, their public lives are ever controlled and monitored by men who are always eager to accuse them of wrong doing.

Those who designed this method of dressing should have taken into consideration the fact that during the dry season especially in Nigeria and the Middle East, the weather becomes very warm to the point that it is even difficult to wear ordinary shirts and move about freely. It is in this type of inclement weather condition that many women are compelled to wear over-flowing silk gown as well as carry heavy load and move about in search of their livelihood. This deplorable condition of the woman again attracted the attention of Daniel Enim who goes further to emphasize the fact that:

Her mode of dressing which involves her covering all parts of her body serves as a means of protection for the man. It is believed that all of a woman's body is specially created to lure men. Therefore, to protect him from sinning the source of temptation has to be covered, irrespective of her feeling about it. This mode of dressing is also meant to testify to her delicate, subdued and submissive nature (190).

From the above, one can see the difficult life style that many women are forced to live in order to be allowed to exist in their society. They move about as mere beings who have no right to express themselves in their religious and social spheres. They simply live to satisfy the demands placed on them by religion so as to be allowed to exist without getting into trouble with the men who determine their fate. Again, many women are used as mere objects to be discarded at any time without honors and consideration. This situation can easily manifest when their husband dies and they become widows merely living without respect by men who many a time order them about to carry out one ritual or obligation. For example, the widow is required to shave her hair as a mark or sign to prove that she is mourning her dead husband. The humiliation and controversies which accompany this shaving rite is better imagined than witnessed as it is so agonizing, tormenting and dehumanizing to the point that one cannot help but cry for the poor and helpless widow who is subjected to some demeaning rites in fulfillment of the cultural requirements to satisfy the dead. Mariama Ba in So Long a Letter seems to lend credence to the above when she laments the fact that:

This is the moment dreaded by every Senegalese woman,

The moment when she sacrifices her possessions as gifts to her family- in-laws, and worse still, beyond her personality, her dignity, becoming a thing in the service of the man who has married her...her behavior is conditioned... (4).

Once there is an expression of uneasiness from the helpless women in this condition against the "order", they are labeled witches and may even be accused of being responsible for the death of the husband. This will in turn prompt yet another purification rite to prove her innocence. Again, in So Long a Letter, we are meant to understand that the two 
widows, $\mathrm{Ba}$ and Binetou were separated from the others and placed in a tent to discourage them from direct link or interaction with their sympathisers. Ba describes their ordeal and humiliation they were subjected when their husband died:

Our sisters-in-laws undo our hair. My co-wife and myself are put inside a rough and ready tent made of a wrapper pulled out above taut our heads and set up for the occasion (4).

She goes further to observe that no sister-in-law will touch the head of wife who has been stingy, unfaithful or unhospitable (4). It is ironical to note that some of the enforcers of these obnoxious treatments against women are sometimes the women themselves who derive joy in mocking their fellow women as cultural victims.

Moreover, it has been noted that during mourning period for their late husband. many women are subjected to some inhuman treatments which include not being allowed to take bath when they like, eating at odd hours and are also required to wear one white or black wrapper and shirt for many days depending on choice and age of the deceased. The dehumanizing experience prompted Ba to lament her deplorable moments while mourning her late husband when she had to change her cloth twice a week. Alone, I live in a monotony broken only by purifying baths, the changing of mourning cloths every Monday and Friday (8). The rites of observances vary from one cultural environment to the other depending on the perception of life. One is at pain to note that most of these agonies and mental tortures meted to many women emanate from their religious background where they are expected to obey even when in difficult situations. Again, Ba recalls those moments of grief in her letter thus:

I hope to carry out my duties fully. My heart concurs with the demands of religion. Reared since childhood on their strict precepts, I expect not fall. The walls that limit my horizon for four months and ten days do not bother me. I have enough memories in me to ruminate upon. And these are what I am afraid of, for they smack of bitterness. (8).

Ba's experience shows how religion has been used as an oppressive instrument to lure the widows to accept what is against fundamental right of existence. Here, they are given no option except to do what the overzealous interpreters of their religion command at that point of mourning.

\section{Politics: Women Representation}

In terms of political relationship within the society, most women are still placed at disadvantaged position. This is because patriarchy has been institutionalized in many parts of Africa such as Senegal, Nigeria, Niger and Mali. In some parts of Nigeria such as Igboland, Yorubaland, Hausaland, the structure of leadership position favors men to the point that women are most of the time excluded from the decision making processes. For example, a look at Senegalese National Assembly shows that female representation is usually reduced to insignificant number and in some cases, they are non-existent due to this negative attitude towards them by men who perceive them as not being strong enough to do politics. Therefore, to ensure there is female presence at the National Assembly, few seats are reserved for the female members unlike their male counterparts who claim to be the rightful persons to occupy these positions. It is based on this note that $\mathrm{Ba}$ is calling attention to the unbalanced political equation and challenges Daouda Dieng to the fact there are only "Four women, Daouda, four out of a hundred deputies. What a ridiculous ratio! Not even one for each province" (60). Doauda wants Ba to feel that women are even represented at National Assembly as deputies no matter the number.

This still very critical, Rammatoulaye! Why this ironical statement and provocative epithet when there are women in the Assembly (60).

This should not have been the case because an equal opportunity ought to be given to them to prove their worth. The above scenario has also been expressed by Mbachaga Desen Jonathan when he notes that:

All societies are patriarchies where men's domination over women are institutionalized through social structures such as the family and religion (160).

He goes further to assert that:

(a) Most societies are ruled by men

(b) The woman is considered as the property of the man.

(c) The man has more right in religion and family (160).

The above seems to imply that through religious and family structures, male dominance over the female is internalized as well as sanctioned. 
Moreover, Ba also stressed that since twenty years after independence no female minister has been elected or appointed despite the fact that women play vital role in the elections. According to her, women have raised more than one to power (61). Even opponent Dauoda Dieng of the National Assembly made similar submission reiterating the need for women participation in politics to represent their interest as he avers that:

Women should no longer be decorative accessories, objects to be moved about, companions to be flattered or calmed with promises. Women are the nation's primary, fundamental root from which all else grows and blossoms.

Women must be encouraged to take a keener interest in the destiny of the country (62).

From the above experience, many have come to the realization that the contributions of the women to the development of the family and nation can no longer be ignored but should be recognized and celebrated.

\section{Social Activities}

On the social sphere, there seems to be the feeling of envy and uneasiness in some cultural environment like Senegal where Mariama Ba was trained. Here, most women are generally considered not good enough to lead. This emanates from the cultural background where some men think they are superior and more intelligent than the women. So, once any woman in this context attempts to show an extra ordinary intelligence or skill, she is castigated as a rebel or rascal who wants to do what others abstain from. When a woman is educated and "out spoken" she is labeled as being pompous and unnecessarily proud. This is the fate of $\mathrm{Ba}$ and her colleagues who were among the first group of African women to be educated. she emphasizes that:

Because of being the first pioneers of the promotion of African women, there were very few of us. Men would call us scatter brain. Others labeled us devils (14-15).

in some African countries such as Senegal and Nigeria, some parents have to approve in some cases even choose the husband for their children especially whom the daughter will marry without considering her feelings. Their concern is to ensure that they are married to someone they consider man enough to be their son-in-law with material resources to care for them. Ba narrates her ordeal when she encountered the disapproval and consternation of her parents for daring to marry a man against their wish when she married Moduo instead of Daouda Dieng.

But I prefer the man in the eternal Khaki suit. Our marriage was celebrated without dowry, without pomp, under the disapproving looks of my father, before the painful indignation of my frustrated mother, under the sarcasm of my surprised sisters in our town (16).

Based on the above, the level of indignation on the part of the parents is seen because Ba rejects the rich man they wanted to marry her. This is the situation many young ladies are confronted in their choice of marriage. In some extreme cases, it is either they accept the man or they will be disowned and chased out of the family home. Ba goes on to describe that experience thus:

We experienced the tiffs and reconciliation of married life. In our different ways, we suffered the social constraints and heavy burdens of custom (19).

In another vein, Binetou had to abandon her Baccalaureat examination because of her marriage to an old man Modou Fall as a second wife after Mariama Ba in order to satisfy her mother's quest to secure the means of livelihood from her marriage. This is very sad development for the young Binetou as she will not have the opportunity of completing her educational career once she goes into marriage at this tender age with anticipated children. Ba comments on this precarious development through her daughter Daba who observes that:

Binetou had a serious problem. The sugar-daddy of the boutique dresses wants to marry Binetou. Just imagine her parents want to withdraw her from school, with only a few months to go before the bac, to marry her off to the sugar-daddy (35).

This marriage is simply based on the need of Binetou's mother to acquire wealth to make her family live comfortably without considering the feelings and the future of her daughter. Binetou and other young ladies in her category are lured into marrying to older men to satisfy their family interests at the detriment of their future advancement and that of the society. Ba emphasizes the fact that Binetou is simply a victim of circumstance when she pointed out that Binetou, like many others, was slaughtered on the altar of affluence (39).

In most African traditional society like Senegal, wives are meant to be inherited as properties when their husband dies by their brother-in-laws depending on their disposition. The younger brother of the deceased is free to approach the wife for marriage and raise children by her. In this case, Modou's elder brother Tamsir proposes to marry Marriama 
during the motions of piety as required by Islam. He did not wait for the mourning period to be over because of fear that the younger brothers may also be interested and so he hurries to be the first to register his intention. While in Ba's residence accompanied by an Imam and Mawdo, he declares his intention.

When you "come out" (of mourning), I shall marry you. You suit me as a wife, and further, you will continue to live here, just as if Modou were not dead. Usually it is the younger brother who inherits his elder brother's wife. wife. In this case, it is the opposite. You are my good luck. I shall marry you. I prefer you to the other one, too frivolous, too young, I advised Modou against that marriage (57).

It is seen from Mawdo's proposal that the inheritance of Modou's widows is a matter of preference for the brothers to choose whom they want without considering the psychological implications on them. In her reaction to Mowdo's proposal, Ba states the obvious:

Did you ever have any affection for your brother? Already you want to build a new home for yourself, over a body that is still warm. While we are praying for Modou, you are thinking of future wedding festivities. Yes! Your strategy is to get in before any other suitor... before Mawdo... who according to custom, can inherit the wife (58).

In this circumstance, the sanctity of marriage has been reduced to mere acquisition through inheritance. Ba goes further to reject this ridiculous debasement of marriage institution when she reiterates and reminds Modou that:

You forget that I have heart, a mind that I am not an object to be passed from hand. Tamsir, purge yourself of your dream of conquest. They have lasted forty days. I shall never be your wife (58).

With the above words of finality Ba bids farewell to Mawdo's moves to acquire her as wife. Mawdo wants to add Ba to his collection of women as wives to bring the number to four that he caged as well as prevented from advancing in life. Through her letter, Ba highlights the dangers of polygamy and the negative implications on the victims-the women who are usually prevented from advancing in life. She concludes with emphasis on its problems and inhibitions to the African women.

You think the problem of polygamy is a simple one. Those who are involved in it know the constraints, the lies, the injustices that weigh down their consciences in return for the ephemeral joys of change (68).

\section{Economic Factors}

In furtherance, it is necessary to make a highlight of the economic factors which contribute as inhibitions to women advancement within the African context. Experience from this presentation has shown that there are clear evidences that most women are generally less empowered than their male counterparts. This is due to the fact that they do not have the financial capacity that will enable them start sustainable business. Owing to lack of funds and basic infrastructures, many women are unable to engage in business ventures that will yield gainful result and as such they are considered to be economically handicapped as well as dependents. In this situation, they find it difficult to influence decisions in the society as they do not have the economic power which most of the time affects the politics. This helpless and worrisome situation has also been highlighted by Irene Agunloye when she pointed the fact that:

It is becoming increasingly evident that the greater the gender disparity in human development, the greater the level of poverty, as women are the most vulnerable of the populations and with least access to power and resources (62).

From this experience, it is noted that as long as most women do not have sustainable economic resources, they will continue to be marginalized by their male counterparts for survival. This situation further weakens their bargaining powers and exposes them to many forms of manipulations.

In most traditional Africa, it is expected that the women remain at home cooking, caring for the children and other domestic chores which are considered not for the men. When a man begins to involve in the above house chores, he is seen as usurping the role of the woman in the home and this to most men is considered "let down". In a typical African traditional society, men are usually discouraged from involving in most domestic chores. This is quite unfortunate and should not have been the case because the duty of the "family upkeep" rests on the man and the woman including their children. Their roles should be complementary and not obligatory on the woman. This is quite apt at this point when the whole world is clamoring for women empowerment which is one of the main focus of the Millennium Development Goals. Our society cannot claim to be progressing when majority of our women are economically powerless. It is very disheartening to note that most of our women and their children have no sustainable means of livelihood which makes them live below poverty level. 


\section{Conclusion}

The trust of this paper is on some of the cultural practices which inhibit the advancement of most women in their "struggles and sufferings" to live a better life. It is also based on the imbalance found in the relationship between men and women which usually results in the domination of the female gender through cultural practices initiated by men and imposed on the women as a means of subjugating them. It is observed that culture which ought to be used for social harmony is twisted in favor of the men at the detriment of the women and this brings about ill feelings and misunderstanding in the society. It is clear that men have continued to feel that it is their "birthright" to rule and dominate the women in every sphere of human endeavors.

In many parts of the world especially Africa, women are subjugated as well as manipulated in the guise of cultural observances which usually discomfort them. They are relegated to the background without being given the opportunity to express opinion in matters concerning them. Our cultural paradigm seems to place limit on the female gender and suggests that no matter how a woman is highly favored she cannot aspire to be a King, Emir, Oba, Imam or even a Priest because culture forbids her from making such an attempt without consideration to her feelings. It is noted that religion which should have been the last hope of the poor and the less privileged is misused and abused as an instrument of oppression against the women. Our submission is that when these cultural inhibitions enumerated above are changed to favor both men and women that the hope for genuine peace and progress will be achieved for all. The fact is that for the progress made so far to unite the human family to be sustained, the rights of women denied in whatever guise should be restored to enable them live freely and continue to make useful contributions to society development.

\section{References}

Agunloye I.S. (Ed). (2006). Women, Theatre and Politics Contemporary Perspective, Ibadan: Sanitez Publisher.

Cultural Policy for Nigeria, Lagos: Federal Government Printer, 1988.

Emenyi, A.I. (2005). Intersection of Gendered Voices; Lagos: Concept Publications Limited.

Inim, D.P.C. (2008). Women as Sex Symbol in Nigerian Home Videos: A Study of Selected Films. in Professor Femi Osofisan International Conference on Performance. Nwankwo, I. et al, (Ed) Lagos: Joytal Printing Press. 198-206.

Mbachaga, Dense Jonathan. (2008). Women Empowerment in John Paper Clark's. the Wives Revolt. in Professor Femi Osofisan International Conference on Performance; Nwankwo I. et al (Ed.). Lagos: Joytal Printing Press. 160-165.

Ododo, E. and Bodunde C. (Ed.). (2010). Obafconfab Book of Proceedings. Abuja: National Commission for Museums and Monuments.

Okwechime, E.O and Ofuani, O.A. (2008). Negotiating the Female Voice: The Example of Osofisan's Tegonni. in Professor Femi Osofisan, International Conference on Performance; Nwankwo, I. et al (Ed.). Lagos Joytal Printing Press. 178-183.

World Bank. (1994). Enhancing Women's Participation in Economic Development: A World Bank Policy Paper; Washington D.C: The World Bank International Bank for Reconstruction and Development.

Cite this article as: A gbasiere, Chijioke (2021). Cultural Inhi bitions as Threat to A dvancement of A frican Women: The Case of M ariama Ba's So L ong a Letter. International J ournal of Languages and Culture. 1(3), 1-7. doi:10.51483/ IJLC.1.3.2021.1-7. 